\title{
The Effect of Organizational Commitment, Competence, and Information Technology on the Performance of Regional Apparatus Organizations (OPD) of the Tojo Una-Una Regency Government and Their Impact on Job Satisfaction
}

\author{
Sovianur Kure*, Muhammad Basir-Cyio, Bakri Hasanuddin \\ Tadulako University, Faculty of Economics and Business, Tadulako University, Palu
}

\begin{abstract}
The purpose of this study is to measure, analyze and explain (1) the effect of organizational commitment on the performance of program achievements and activities of the Regional Apparatus Organization (OPD) of Tojo Una-Una Regency. (2) The influence of HR competence on the performance of program achievements and activities of the Regional Apparatus Organization (OPD) of Tojo Una-Una Regency. (3) The influence of information technology on the performance of program achievements and activities of the Regional Apparatus Organization (OPD) of Tojo Una-Una Regency. (4) The influence of the performance of program achievements and activities of Regional Apparatus Organizations (OPD) on job satisfaction. (5) The effect of organizational commitment on job satisfaction. (6) The influence of HR competence on job satisfaction. (7) The effect of information technology on job satisfaction. This type of research uses descriptive and causality-hypothesis testing using structural equation modeling with a sample count of 200 respondents. The analysis results show that (1) organizational commitment has a positive and significant impact on the program's performance and activities of the Regional Apparatus Organization (OPD) of Tojo Una-Una Regency. (2) HR competence positively impacts the program's performance and activities of the Regional Apparatus Organization (OPD) of Tojo Una-Una Regency. (3) Information technology has a positive and significant effect on the program's performance and activities of the Regional Apparatus Organization (OPD) of Tojo Una-Una Regency. (4) The performance of program achievements and activities of Regional Apparatus Organizations (OPD) has a positive but not significant effect on job satisfaction. (5) Organizational commitment has a positive and significant effect on job satisfaction of the Regional Apparatus Organization (OPD) of Tojo Una-Una Regency. (6) HR competence has a positive and significant effect on job satisfaction of the Regional Apparatus Organization (OPD) of Tojo Una-Una Regency. (7) Information technology has a positive and significant effect on job satisfaction of the Regional Apparatus Organization (OPD) of Tojo Una-Una Regency.
\end{abstract}

Keywords: Organizational Commitment, Competence, Information Technology, Job Satisfaction Performance.

\section{INTRODUCTION}

$\mathrm{T}$ he performance of Regional Government Organizations (OPD) is the spearhead of government performance in each district/city. OPD at the managerial level is the implementer who implements the vision and mission of a regional head through the programs and activities contained in the RPJMD (Regional Medium-Term Development Plan), Renstra (Strategic Plan), Renja (Work Plan), and RKA (Budget Work Plan). Performance Measurement of Program Achievements and Activities of Regional Apparatus Organizations (OPD) so far has focused more on the performance of financial or financial absorption. Therefore, approaches other than economic or financial can refer to the concept of performance developed by Pada Kaplan \& Norton (1996), known as the Balanced Score Card (BSC). There are 4 (four) perspectives in the BSC, namely (1) Financial Perspective (Financial); (2) Customer Perspective; (3) Internal Business Process Perspective; and (4) Growth and Learning Perspective. Implementation of the Balanced Scorecard in the Public Sector in the international world itself BSC has been applied in many government institutions, both at the central and regional levels (Nor, 2012; Amirudin et al., 2021; Octaviane, 2021; Huy \& Phuc, 2020 danBobe et al. 2017).

To achieve the performance that has been stated in the OPD, a high commitment is needed, as Mowday et al. (1983) said work commitment is another term for organizational commitment, where organizational commitment is an important behavioral dimension that can be used to assess the tendency of employees to remain as members of the organization. Further, Robbins \& Thimoty (2018) explain that organizational commitment is a condition in which an employee sided with a particular organization and its goals and desires to maintain membership in the organization. Empirical research on organizational commitment provides evidence that organizational commitment has a positive and significant effect on employee performance; this result is supported by (Gunawan et al., 2017; Sharma et al., 2021; Krajcsák, 2021 and Rantelangi et 
al., 2017).

Implementation of employee performance requires not only high commitment but also competence to carry out the duties of each employee. According to Noe (2002), the implementation of competence at the managerial level is needed, namely the person's ability, which includes knowledge, skills, attitudes, values, or personal characteristics that enable workers to achieve success in completing tasks. According to Spencer \& Signe (1993), several types of competence are the components of individual competence: (1). Intellectual competence, (2). Emotional competence, (3). Social competence. Research on competence on performance has been carried out by many researchers, including (Revelation, 2021; Young et al., 2017 and Irvan et al., 2017).

To realize organizational performance in terms of work efficiency, economy, and work effectiveness, the role of technology in all sectors cannot be avoided, including the government sector, in improving superior services to the community. The OPD in Tojo Una-Una Regency has been equipped with an application system, especially in budget planning and making RKA. As opinionHasibuan \& Santoso (2005) and Dash \& Pani (2016), E-government is a very important thing to have.

The issue of the era of disruption of the industrial revolution 4.0 has an impact on the business sector and government services required to adjust quickly, accurately, and efficiently. One of the critical characteristics of the industrial revolution 4.0 is the speed with which organizations and individuals experience change, as emerging technological innovations create ways to develop, exchange, and distribute value across society (Ihsan, 2018; Gokmen, 2010; Andika et al., 2019; Ali et al.; 2021 and Yu et al., 2021). The utilization of information technology in the preparation of planning and monitoring and performance evaluation will make it easier to evaluate the performance of the achievements of OPD programs and activities, which are carried out every Quarter (TW) by the Bappeda Team and the Inspectorate.

The Tojo Una-Una Regency Government gives awards to OPDs who have $100 \%$ financial performance and minimal findings. The award is provided in the form of an additional budget ceiling, and if there are findings, the return can be paid in installments according to ability. This policy is to improve performance and ultimately provide employee job satisfaction in each OPD. The concept of job satisfaction that job satisfaction as effectiveness or emotional response to various aspects of work (Robert \& Kinicki, 2015; Robbins \& Coulter, 2010; Lotunani et al., 2014; Destari et al., 2018; Gede et al., 2018; Chanda \& Goyal, 2020 and Ridlwan et al., 2021).

Based on the background and observing all the previous research that has been revealed, both its advantages and disadvantages, it can show a research gap, which is considered and believed to be a novelty and has never been studied before, namely the research gap of this dissertation lies in the position of the Information Technology variable and Job satisfaction; Variables of Organizational Commitment and Job Satisfaction; Variables Organizational Commitment, Competence, and Job Satisfaction. So that the authors can map what has never been studied by previous researchers, the authors are interested in submitting the title "The Influence of Organizational Commitment, Competence and Information Technology on the Performance of Regional Apparatus Organizations (OPD) of the Tojo Una-Una Regency Government and Its Impact on Job Satisfaction."

\section{LITERATURE REVIEW}

\section{Relationship of Research Variables}

Relationship between Organizational Commitment and Performance

Previous researchers have carried out studies on organizational commitment, and empirical evidence shows that organizational commitment has a significant effect on employee performance (Trisnaningsih, 2017; Princess, 2010; Zefeiti et al., 2017; Macey \& Schneider, 2008; Casimir et al., 2014 and Folorunso et al., 2014). In general, this study supports the suggestion from previous research that organizational commitment significantly influences employee performance (Araújo \& Lopes, 2014; Fu and Deshpande, 2014; Kalkavan and Katrinli, 2014; Sani, 2013). However, these findings are not in line with empirical findings from Nurul (2012) and Fifien (2015), which state that organizational commitment does not affect individual or employee performance. Based on previous empirical studies and studying the theories that have been described previously, the following hypotheses are formulated:

\section{H1: Organizational commitment has a positive and significant effect on the performance of the Regional Apparatus Organization (OPD) of the Tojo Una-Una Regency Government}

\section{Relationship between Competence and Performance}

Empirical studies of competencies related to employee performance have been carried out, among others by Harun (2012). Measurement of employee competence in his research developed a competency measurement of Spencer \& Spencer (1993), which includes: (1) Motives, (2) Characteristics, (3 ) Self-Concept, (4) Knowledge, and (5) Skills. Empirical evidence shows that managerial competence has a positive effect on governance and HR capacity has a positive and significant impact on the timeliness of financial reporting (Abbas and Wahyudin; 2017). This finding was rejected by other researchers, that Auditor Competence has a negative and insignificant impact on governance (Harun, 2012; Dadang, 2015; Nurul and Wahyudin, 2017). Auditor competence has a negative effect and has no significant impact on financial performance (Harun, 2012 and Nurul and Wahyudi, 2017). Based on previous empirical studies and studying the theories that have been described previously, the following hypotheses are formulated: 
H2: Competence has a positive and significant effect on the performance of the Regional Apparatus Organization (OPD) of the Tojo Una-Una Regency Government

The Relationship of Information Technology with Performance

Empirical research on the importance of Egovernment has been carried out by Aytac (2010). The use of information technology will improve the performance of local government officials and prepare financial reporting. Furthermore, Wilkinson (2000) said the use of information technology includes (a) data processing, information processing, management systems, and work processes electronically and (b) the use of advanced information technology so that public services can be accessed quickly and cheaply by the public. Use information technology if the technology is valuable and can improve performance (Lestari and Zulaikha, 2007; Rahman \& Fachri, 2016; Kabiru et al., 2015; Rahman \& Fachri, 2016; and Ayu, (2017). In addition, the conclusion of Wigrantoro (2003) states that the use of information technology is not within the framework of good governance but is only used as a tool to facilitate work. This study found that information technology did not significantly impact the quality of local government financial reports (Dadang, 2015). Based on previous empirical research and paying attention to the theoretical explanation, the hypothesis is proposed as follows:

H3: Information technology has a positive and significant effect on the performance of the Regional Apparatus Organization (OPD) of the Tojo Una-Una Regency Government

\section{Linkages Performance with Job Satisfaction}

Research on the effect of performance on satisfaction has not been done much. Previous researchers were more likely to measure job satisfaction on the performance of employees in the private sector. However, not much has been done in the government sector, especially for employees with civil servant status. Average theoretical support explains that satisfaction affects performance (Argensia et al., 2014; Rosita and Yuniati, 2016; Niemiec and Spence, 2017; Judge et al., 2017; Kendall, 1963); Hulin 2001; Nhuta, 2017 and Rue and Byars, 2003). Aziri (2011) and Squires et al. (2015) emphasized that when discussing job satisfaction, job dissatisfaction must be considered to ensure balance. Other than that, A study conducted by Bos et al. (2009) aims to obtain an intuition about job satisfaction from the point of view of employees who argue that job satisfaction has five determinants consisting of independence, the flexibility of skills, support from superiors, opportunities, further education and relationships with employees. Work colleague. Employees must be preserved and fundamentally well thought out because human beings who have their wants, needs, and desires are a perfect scale for job excellence (Mustofa \& Jamal, 2013).
Furthermore, Aziri (2011) argues that there is no strong relationship between job satisfaction and employee performance. Regulation of the Head of the State Civil Service Agency Number 20 of 2011 concerning Guidelines for Calculation of Performance Allowances for Civil Servants. What is meant by Performance Allowance is the allowance given to Civil Servants whose amount is based on the results of the evaluation of positions and the work performance of Civil Servants. Based on previous empirical research and paying attention to theoretical explanations, as well as government regulations, the hypothesis is proposed as follows:

\section{H4: The Performance of Regional Apparatus Organizations (OPD) has a significant effect on Job Satisfaction}

Linkages Organizational Commitment with Job Satisfaction

Previous researchers have carried out the relationship between organizational commitment and job satisfaction, which revealed a significant effect between organizational commitment on job satisfaction and performance (Saputra, 2020; Wahab et al., 2021; Luoto et al., 2001 and Gopinath, 2021). It was further explained that job satisfaction has a positive relationship with employee commitment. If employees are satisfied, they are organizationally committed. We found that job satisfaction has a positive impact on employee commitment. Based on previous empirical research and paying attention to the theoretical explanation, the hypothesis is proposed as follows:

H5: Organizational Commitment has a significant effect on Job Satisfaction

\section{Relationship between Competence and Job Satisfaction}

Research on the Relationship between Competence and Job Satisfaction, evidence of this support has been carried out by researchers who say that competence has a significant effect on job satisfaction (Akram \& Anwer, 2015; Che et al., 2021; Sabuhari et al., 2020 and Wang et al., 2020). Based on previous empirical research and paying attention to the theoretical explanation, the hypothesis is proposed as follows:

\section{H6: Competence has a positive and significant effect on Job Satisfaction}

The Relationship of Information Technology with Job Satisfaction

Research on the relationship of information technology with job satisfaction, evidence of this support has been carried out by previous researchers who say that information technology has a significant effect on job satisfaction. With the proliferation of information technology (IT) in the workplace, employee satisfaction with workplace IT is becoming an integral part of the job and significantly affects work-related outcomes. Furthermore, it was explained that job fit was mediated and strengthened the influence of IT satisfaction at work on job satisfaction. In contrast, professional fit did not play a moderate role in the relationship 
between IT satisfaction at work and job satisfaction. The findings suggest that practitioners should emphasize IT as an important element of the work context and enhance employees' experience using IT. More importantly, the fit of IT to the employee's job and professional requirements is critical to the satisfaction transition (Sapta et al., 2021; Achmad et al., 2021 and Wang et al., 2020). Based on previous empirical research and paying attention to the theoretical explanation, the hypothesis is proposed as follows:

\section{H7: Information Technology has a positive and significant effect on Job Satisfaction}

\section{The Conceptual Framework}

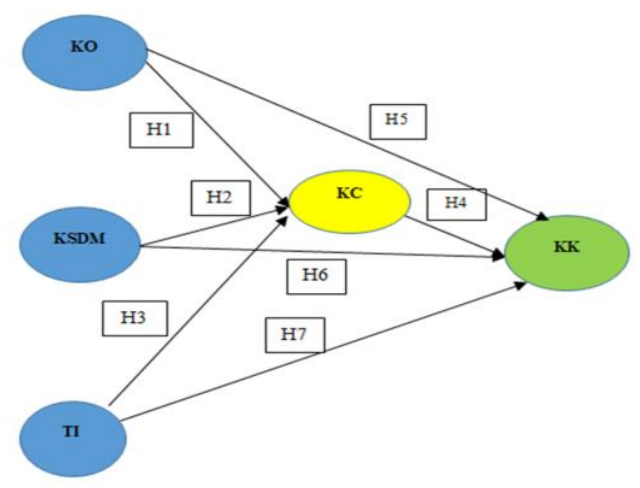

Figure 1. The conceptual framework

\section{METHODOLOGY}

Types of Research

This type of dissertation research is descriptive and causal. According to Sekaran (2017), descriptive research (descriptive reset) aims to describe the characteristics, aspects of the phenomenon of relevant interest from people, events, or situations in the form of qualitative data collection. Descriptive research will assist the author in explaining the indicators of the measured variables. While causal research (causal) is to tests the hypothesis of the influence between the variables studied. Furthermore, quantitative research is research whose data is quantitative, so that the data analysis uses quantitative analysis (inference).

\section{Sampling}

The population in this study is the Strategic, Tactical, and Operational Management in the OPD Environment of Tojo Una-Una Regency, which is echelon II, III, and IV as many as 687 people. In this study using the Structural Equation Modeling (SEM) analysis tool, the sample size must meet the minimum sample size for applying the SEM model. In general, the structural equation model has at least 200 observations. Based on the opinion reference above, the researchers set 200 samples. From a total sample of 200 samples, it will be distributed by proportional sampling with the division of Echelon One employees amounting to 1 person, Echelon two totaling 10 people, Echelon three 43 people, and Echelon four totaling 146 people. Seeing this division, the suitable sampling technique is proportionate stratified random sampling. According to Sugiyono (2015), proportional stratified random sampling is a way of taking samples into account the strata (levels) in the population. The previous stratified data were grouped into certain levels, such as echelon levels in government.

\section{Analysis Method}

The data analysis method in this research uses descriptive and verification analysis (through statistical tools) to prove the proposed hypothesis. This study uses descriptive analysis of the independent and dependent variables, classified into the total number of respondents' scores. From the total score of respondents' answers obtained, the assessment criteria are arranged for each statement item. The analysis stage is carried out to the scoring and index. The score is the sum of the multiplication results of each weighted value (1 to 5) frequency-verificative analysis to test hypotheses built based on the framework and research structure model. The statistical tool used is SEM (Structural Equation Modeling). The data analysis technique using Structural Equation Modeling (SEM) was carried out to explain the relationship between the variables in the study thoroughly. In general, an SEM model can be divided into two main parts, namely the Measurement model and the Structural model. According to Hair et al. (2006), there are 7 (seven) steps that must be taken when using Structural Equation Modeling (SEM), namely:

Table 1: Steps of Structural Equation Modeling (SEM)

\begin{tabular}{|c|c|}
\hline Criteria & description \\
\hline $\begin{array}{c}\text { Theoretical } \\
\text { Model } \\
\text { Development }\end{array}$ & $\begin{array}{l}\text { Conducting a series of scientific explorations through } \\
\text { literature review to obtain justification for the theoretical } \\
\text { model to be developed }\end{array}$ \\
\hline $\begin{array}{c}\text { Flowchart } \\
\text { Development }\end{array}$ & $\begin{array}{l}\text { The constructs built in the flowchart can be divided into } \\
\text { two groups, namely: } \\
\text { 1) Exogenous constructs, also known as source variables } \\
\text { or independent variables, will be predicted by other } \\
\text { variables in the model. An exogenous construct is a } \\
\text { construct addressed by a line with one arrowhead. } \\
\text { 2) Endogenous constructs, which are factors that are } \\
\text { predicted by one or more constructs. Endogenous } \\
\text { constructs can predict other endogenous constructs, } \\
\text { but exogenous constructs can only be causally } \\
\text { related to endogenous constructs. }\end{array}$ \\
\hline $\begin{array}{l}\text { Convert } \\
\text { flowcharts to } \\
\text { equations }\end{array}$ & $\begin{array}{l}\text { 1) Structural equations (structural equations) are } \\
\text { formulated to express causality between various } \\
\text { constructs. Endogenous variable = exogenous variable }+ \\
\text { endogenous variable + error } \\
\text { 2) Equation the measurement model specification, which } \\
\text { must determine the variables that measure the construct } \\
\text { and select a series of matrices showing the correlation } \\
\text { between the constructs or variables. }\end{array}$ \\
\hline $\begin{array}{c}\text { Selecting the } \\
\text { input matrix and } \\
\text { model } \\
\text { estimation }\end{array}$ & $\begin{array}{l}\text { SEM uses input data that only uses a variance/covariance } \\
\text { matrix or a correlation matrix for the overall estimate. } \\
\text { Covariance matrices are used because SEM has the } \\
\text { advantage of providing valid comparisons between } \\
\text { different populations or different samples, which } \\
\text { correlation cannot offer. }\end{array}$ \\
\hline $\begin{array}{c}\text { Possible } \\
\text { identification }\end{array}$ & $\begin{array}{l}\text { The identification problem is principally a problem } \\
\text { regarding the inability of the developed model to produce }\end{array}$ \\
\hline
\end{tabular}




\begin{tabular}{|c|c|}
\hline problems & $\begin{array}{l}\text { a unique estimate. If the estimation is made and an } \\
\text { identification problem arises, the model should be } \\
\text { reconsidered by creating more constructs. }\end{array}$ \\
\hline $\begin{array}{l}\text { Evaluation of } \\
\text { goodness of fit } \\
\text { criteria }\end{array}$ & $\begin{array}{l}\text { Chi-square test, where the model is considered excellent } \\
\text { or satisfactory if the Chi-square value is low. The smaller } \\
\text { the chi-square value, the better the model, and the } \\
\text { significance value is greater than the cut-off value } \\
\text { (p>0.05). } \\
\text { 2) RMSEA (The Root Mean Square Error of } \\
\text { Approximation), which shows the goodness of fit that can } \\
\text { be expected when the model is estimated in the } \\
\text { population (Hair et al., 2006). The RMSEA value, which } \\
\text { is less than or equal to 0.08, is an index for the } \\
\text { acceptance of the model, which shows a close fit of the } \\
\text { model based on the degrees of freedom. } \\
\text { 3) GFI (Goodness of Fit Index) is a non-statistical } \\
\text { measure that has a range of values between } 0 \text { (poor fit) to } \\
\text { 1.0 (perfect fit). A high value in this index indicates a } \\
\text { "better fit." } \\
\text { 4) AGFI (Adjusted Goodness of Fit Index), where the } \\
\text { recommended level of acceptance is if AGFI has a value } \\
\text { equal to or greater than } 0.90 \text {. } \\
5 \text { ) CMIN/DF is The Minimum Sample Discrepancy } \\
\text { Function divided by the Degree of Freedom. The chi- } \\
\text { square divided by the DF is called the relative chi-square. } \\
\text { If the relative chi-square value is less than } 2.0 \text { or } 3.0 \text {, it } \\
\text { indicates an acceptable fit between the model and the } \\
\text { data. } \\
\text { 6) TLI (Tucker Lewis Index) is a cumulative index that } \\
\text { compares a tested model against a baseline model. A } \\
\text { model of } 0.95 \text { and a value close to } 1 \text { indicates a perfect } \\
\text { fit. } \\
\text { 7) CFI (Comparative Fit Index), where if it is close to } 1 \text {, } \\
\text { it indicates the highest level of fit. The recommended } \\
\text { value is CFI } 0.94 \text {. }\end{array}$ \\
\hline $\begin{array}{c}\text { Model } \\
\text { interpretation } \\
\text { and } \\
\text { modification }\end{array}$ & $\begin{array}{l}\text { The last stage is interpreting the model and modifying the } \\
\text { model for models that do not meet the testing } \\
\text { requirements. The purpose of the modification is to see if } \\
\text { the made changes can reduce the chi-square value; As is } \\
\text { known, the smaller the chi-square number indicates, the } \\
\text { more fit the model is with the existing data. }\end{array}$ \\
\hline
\end{tabular}

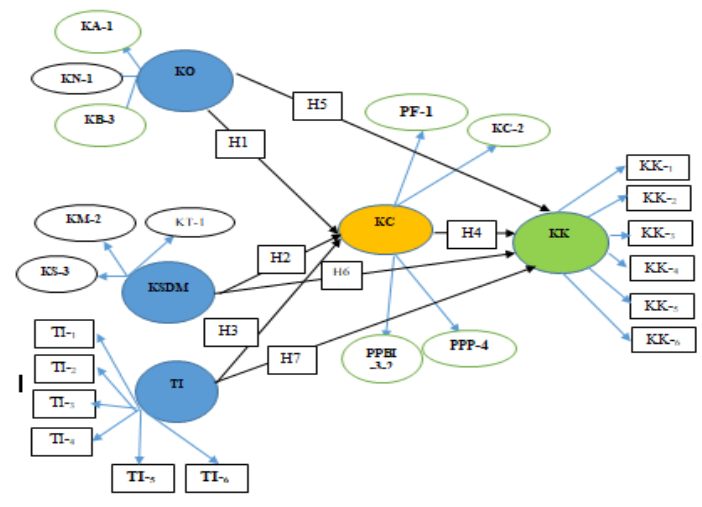

Figure 2:Research Structure Model

\section{RESULTS INTERPRETATIONS}

\section{Respondent profile}

The frequency and percentage of research respondents are shown in Table 2 . The results showed that the frequency of the respondents' gender indicated that the male sex dominated the respondents, namely $67.5 \%$ or 135 people. At the same time, the rest are female by $32.5 \%$. The frequency of respondents' age shows that the age distribution of respondents is mainly at the age of $>40-50$ years, namely 97 people or $48.5 \%$, then the distribution at the age $>50-60$ years is 66 people or $33 \%$, and the rest is in the age distribution between $30-40$ years, namely 37 people or $18.5 \%$. The frequency of respondent education shows that the most respondents' education distribution is in undergraduate teaching (S1), 147 people or $73 \%$. In the distribution of master's education, 47 people or $23 \%$, and the rest are vocational/high school education. And there is 1 respondent with a doctorate in public administration. Tabulation of the frequency of respondents' structural positions shows that the distribution of most respondents' structural parts is in echelon III structural positions, namely 112 people or $56 \%$. The distribution in echelon IV structural positions is 78 people or $39 \%$, and the rest is in the distribution of structural positions echelon II is 10 people. Or 5\%. The details can be presented in Table 2:

Table 2: Summary Of Profile Of Respondents

\begin{tabular}{|c|c|c|c|}
\hline $\begin{array}{c}\text { Construc } \\
\text { ts }\end{array}$ & Items & Frequency & Valid Percent (\%) \\
\hline Gender & Man & 135 & 67.5 \\
\hline Age & $>30-40$ & 75 & 32.5 \\
\hline & $>40-50$ & 97 & 48.5 \\
\hline & $>50-60$ & 37 & 33 \\
\hline $\begin{array}{c}\text { Educatio } \\
\text { n }\end{array}$ & $\begin{array}{c}\text { SMA/SMK/Gymnas } \\
\text { ium }\end{array}$ & 5 & 18.5 \\
\hline & $\begin{array}{c}\text { Bachelor/Bachelor } \\
\text { degree }\end{array}$ & 147 & 3 \\
\hline & Master & 47 & 73 \\
\hline & Doctor & 1 & 23 \\
\hline Position & Echelon I & 0 & 0 \\
\hline & Echelon II & 10 & 5 \\
\hline & Echelon III & 112 & 56 \\
\hline & Echelon IV & 78 & 39 \\
\hline
\end{tabular}

Measurement model

The validity and reliability test measurement model follows the Loading factor ( ) and Composite Reliability (CR) and Probability (p). The results show that all indicators are declared valid and reliable based on the size of the Loading factor ( )) and Composite Reliability (CR) and Probability (p) are higher than the required value. Furthermore, according to Hair et al. (2014), the value of construct validity can be observed through the estimation coefficient $(\lambda)$. This coefficient is valid, meaning that the variable observatory used can represent a construct at $>0.50$. This study is guided by the provisions recommended by Ferdinand (2014), namely CR $>2.00$ and the estimated coefficient $(\lambda)$ or loading factor recommended by Hair et al. (2014) CR value of CR > 2.00. The higher the loading factor, the better. 
Table 3: Measurement model results

\begin{tabular}{|c|c|c|c|c|c|}
\hline \multirow{2}{*}{ Variable } & \multirow{2}{*}{ Dimension } & \multirow{2}{*}{ Items } & \multirow{2}{*}{$\begin{array}{l}\text { Loading } \\
\text { factor ( } \\
\text { ) }\end{array}$} & $\mathrm{CR} / \mathrm{t}$ & \multirow{2}{*}{$\begin{array}{l}\text { Probability } \\
\text { (p) }\end{array}$} \\
\hline & & & & Count & \\
\hline \multirow{12}{*}{$\begin{array}{l}\text { Organizational } \\
\text { Commitment }\end{array}$} & \multirow{4}{*}{ Affective } & $\mathrm{X} 1.1$ & 0.514 & 5.098 & 0.000 \\
\hline & & $\mathrm{X} 1.2$ & 0.948 & 3.468 & 0.000 \\
\hline & & $\mathrm{X} 1.3$ & 0.547 & 2,955 & 0.003 \\
\hline & & $\mathrm{X} 1.4$ & 0.444 & & \\
\hline & \multirow{4}{*}{ normative } & $\mathrm{X} 1.5$ & 0.402 & 3.746 & 0.000 \\
\hline & & $\mathrm{X} 1.6$ & 0.585 & 3.325 & 0.000 \\
\hline & & $\mathrm{X} 1.7$ & 0.509 & 3.438 & 0.000 \\
\hline & & $\mathrm{X} 1.8$ & 0.515 & & \\
\hline & \multirow{4}{*}{ Sustainable } & X1.9 & 0.487 & 2,928 & 0.003 \\
\hline & & $\mathrm{X} 1.10$ & 0.575 & 3,733 & 0.000 \\
\hline & & $\mathrm{X} 1.11$ & 0.465 & 2,923 & 0.003 \\
\hline & & $\mathrm{X} 1.12$ & 0.568 & & \\
\hline \multirow{12}{*}{ Competence } & \multirow{4}{*}{ Technical } & $\mathrm{X} 2.1$ & 0.589 & 4.217 & 0.000 \\
\hline & & $\mathrm{X} 2.2$ & 0.433 & 3.516 & 0.000 \\
\hline & & $\mathrm{X} 2.3$ & 0.556 & 4.423 & 0.000 \\
\hline & & $\mathrm{X} 2.4$ & 0.628 & & \\
\hline & \multirow{4}{*}{ Managerial } & $\mathrm{X} 2.5$ & 0.728 & 5.783 & 0.000 \\
\hline & & $\mathrm{X} 2.6$ & 0.704 & 6.136 & 0.000 \\
\hline & & $\mathrm{X} 2.7$ & 0.618 & 6.189 & 0.000 \\
\hline & & $\mathrm{X} 2.8$ & 0.557 & & \\
\hline & \multirow{4}{*}{$\begin{array}{l}\text { Socio- } \\
\text { cultural }\end{array}$} & X2.9 & 0.516 & 4.380 & 0.000 \\
\hline & & $\mathrm{X} 2.10$ & 0.592 & 4,586 & 0.000 \\
\hline & & $\mathrm{X} 2.11$ & 0.533 & 4.444 & 0.000 \\
\hline & & $\mathrm{X} 2.12$ & 0.575 & & \\
\hline \multirow{6}{*}{\multicolumn{2}{|c|}{ Information Technology }} & $\mathrm{X} 3.1$ & 0.631 & 5.367 & 0.000 \\
\hline & & $\mathrm{X} 3.2$ & 0.703 & 5.552 & 0.000 \\
\hline & & X3.3 & 0.522 & 4.860 & 0.000 \\
\hline & & $\mathrm{X} 3.4$ & 0.489 & 4.668 & 0.000 \\
\hline & & X3.5 & 0.515 & 6.260 & 0.000 \\
\hline & & $\mathrm{X} 3.6$ & 0.521 & & \\
\hline \multirow{10}{*}{$\begin{array}{l}\text { Performance } \\
\text { Achievements }\end{array}$} & \multirow{4}{*}{$\begin{array}{l}\text { Financial } \\
\text { Perspective }\end{array}$} & Y1.1 & 0.606 & 6.372 & 0.000 \\
\hline & & Y1.2 & 0.668 & 6.209 & 0.000 \\
\hline & & Y1.3 & 0.728 & 5.892 & 0.000 \\
\hline & & $\mathrm{Y} 1.4$ & 0.591 & & \\
\hline & \multirow{4}{*}{$\begin{array}{l}\text { Customer } \\
\text { Perspective }\end{array}$} & $\mathrm{Y} 1.5$ & 0.562 & 5.594 & 0.000 \\
\hline & & Y1.6 & 0.754 & 6.159 & 0.000 \\
\hline & & Y1.7 & 0.572 & 5.659 & 0.000 \\
\hline & & Y1.8 & 0.605 & & \\
\hline & \multirow{2}{*}{$\begin{array}{l}\text { Internal } \\
\text { process } \\
\text { perspective }\end{array}$} & Y1.9 & 0.696 & 4.649 & 0.000 \\
\hline & & Y1.10 & 0.490 & 4.398 & 0.000 \\
\hline
\end{tabular}

\begin{tabular}{|c|c|c|c|c|c|}
\hline & & Y1.11 & 0.449 & 4.165 & 0.000 \\
\hline & & Y1.12 & 0.561 & & \\
\hline & \multirow{3}{*}{$\begin{array}{l}\text { Growth } \\
\text { and } \\
\text { learning } \\
\text { perspective }\end{array}$} & Y1.13 & 0.539 & 3.069 & 0.002 \\
\hline & & Y1.14 & 0.442 & & \\
\hline & & Y1.15 & 0.593 & & \\
\hline \multirow{6}{*}{ Job satisfaction } & & Y2.1 & 0.551 & 5.524 & 0.000 \\
\hline & & $\mathrm{Y} 2.2$ & 0.518 & 5.769 & 0.000 \\
\hline & & Y2.3 & 0.471 & 5.073 & 0.000 \\
\hline & & Y2.4 & 0.532 & 4.686 & 0.000 \\
\hline & & Y2.5 & 0.697 & 6.084 & 0.000 \\
\hline & & Y2.6 & 0.619 & & \\
\hline
\end{tabular}

Note: Loading factor ( ), Composite Reliability (CR), Probability (p)

Structural Model

The measurement of the construct of the research model The Effect of Organizational Commitment, Competence, and Information Technology on the Performance of Program Achievements and Activities of Regional Apparatus Organizations (OPD) and Their Impact on Job Satisfaction. To test the model using Structural Equation Modeling on the AMOS 20.0 program. Based on the results of the Confirmatory Factor Analysis (CFA) test, it can be presented in the following figure:

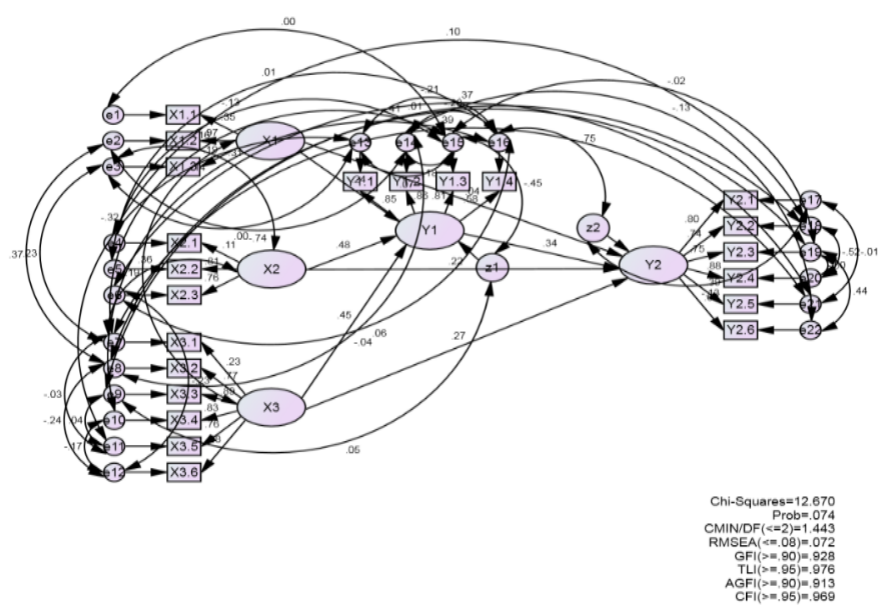

Figure 3: Structural model results

Furthermore, to determine the level of suitability or feasibility of the overall model (Overall Model) of the research model, construct the Effect of Organizational Commitment, HR Competence, and Information Technology on the Performance of Program Achievements and Activities of Regional Organizational Organizations (OPD) and Their Impact on Job Satisfaction, it can be seen that Goodness Of Fit Index (GFI) is an index that describes the overall level of fit of the model which is calculated from the squared residual of the predicted model compared to the actual data, in detail it can be presented in the following table. 
Table 4: Criteria EvaluationGoodness of Fit Index Overall Model constructs research model.

\begin{tabular}{|c|c|c|c|c|c|}
\hline \multirow{2}{*}{ Criteria } & \multirow{2}{*}{ Cut Of Value } & \multicolumn{2}{|c|}{$\begin{array}{c}\text { Model Computing } \\
\text { Results }\end{array}$} & \multicolumn{2}{c|}{ Model Evaluation } \\
\cline { 3 - 6 } & $\begin{array}{c}\text { EAR } \\
\text { LY } \\
\text { CFA }\end{array}$ & $\begin{array}{c}\text { FINAL } \\
\text { CFA }\end{array}$ & $\begin{array}{c}\text { CFA } \\
\text { BEINNI } \\
\text { NG }\end{array}$ & $\begin{array}{c}\text { CFA } \\
\text { END }\end{array}$ \\
\hline $\begin{array}{c}\text { Chi- } \\
\text { square }\end{array}$ & $\begin{array}{c}\text { Expected } \\
\text { small }\end{array}$ & $\begin{array}{c}211,9 \\
26\end{array}$ & 12,670 & Not good & Well \\
\hline $\begin{array}{c}\text { Probabil } \\
\text { ity }\end{array}$ & 0.05 & 0.003 & 0.074 & Not good & Well \\
\hline $\begin{array}{c}\text { CMIN/ } \\
\text { DF }\end{array}$ & 2.00 & 4.125 & 1,443 & Not good & Well \\
\hline $\begin{array}{c}\text { RMSE } \\
\text { A }\end{array}$ & 0.08 & 0.672 & 0.072 & Not good & Well \\
\hline GFI & 0.90 & 0.790 & 0.928 & Not good & Well \\
\hline TLI & 0.95 & 0.834 & 0.976 & Not good & Well \\
\hline AGFI & $\geq 0.90$ & 0.888 & 0.913 & Not good & Well \\
\hline CFI & 0.95 & 0.822 & 0.969 & Not good & Well \\
\hline
\end{tabular}

Hypothesis

Testing the first hypothesis, there is a positive and significant relationship between organizational commitment and performance. Testing the second hypothesis, there is a positive and meaningful relationship between HR competence and performance. Testing the third hypothesis, there is a positive and significant relationship between information technology and performance. Testing the fourth hypothesis, there is a positive and meaningful relationship between performance and performance satisfaction. Testing the fifth hypothesis, there is no significant relationship between organizational commitment and job satisfaction. However, it has a positive direction. Testing the sixth hypothesis, there is a positive and significant relationship between HR competence and job satisfaction. Testing the seventh hypothesis, there is a positive and significant relationship between information technology and job satisfaction.

Table 5: Hypothesis Testing

\begin{tabular}{|c|c|c|c|c|c|}
\hline Track & $\begin{array}{c}\text { Regressi } \\
\text { on } \\
\text { Weight }\end{array}$ & SE & $\begin{array}{c}\text { Critic } \\
\text { al } \\
\text { Ratio }\end{array}$ & $\begin{array}{c}\text { Probabili } \\
\text { ty (p) }\end{array}$ & Information \\
\hline $\begin{array}{c}(\mathrm{X} 1) \rightarrow \\
(\mathrm{Y} 1)\end{array}$ & 0.238 & 0.310 & 2,060 & .039 & $\begin{array}{c}\text { Positive and } \\
\text { Significant }\end{array}$ \\
\hline $\begin{array}{c}(\mathrm{X} 2) \rightarrow \\
(\mathrm{Y} 1)\end{array}$ & 0.479 & 0.830 & 5.501 & .000 & $\begin{array}{c}\text { Positive and } \\
\text { Significant }\end{array}$ \\
\hline $\begin{array}{c}(\mathrm{X} 3) \rightarrow \\
(\mathrm{Y} 1)\end{array}$ & 0.446 & 0.257 & 3,729 & .000 & $\begin{array}{c}\text { Positive and } \\
\text { Significant }\end{array}$ \\
\hline $\begin{array}{c}(\mathrm{Y} 1) \rightarrow \\
(\mathrm{Y} 2)\end{array}$ & 0.336 & 0.131 & 2,982 & .003 & $\begin{array}{c}\text { Positive and } \\
\text { Significant }\end{array}$ \\
\hline $\begin{array}{c}(\mathrm{X} 1) \rightarrow \\
(\mathrm{Y} 2)\end{array}$ & 0.035 & 0.189 & 0.579 & .562 & $\begin{array}{c}\text { Positive but not } \\
\text { Significant }\end{array}$ \\
\hline $\begin{array}{c}(\mathrm{X} 2) \rightarrow \\
(\mathrm{Y} 2)\end{array}$ & 0.222 & 0.099 & 2.485 & .013 & $\begin{array}{c}\text { Positive and } \\
\text { Significant }\end{array}$ \\
\hline $\begin{array}{c}\mathrm{X} 3) \rightarrow \\
(\mathrm{Y} 2)\end{array}$ & 0.266 & 0.245 & 2,702 & .007 & $\begin{array}{c}\text { Positive and } \\
\text { Significant }\end{array}$ \\
\hline
\end{tabular}

V. DISCUSSION

Organizational commitment has a positive and significant effect on the Performance of Regional Apparatus Organizations (OPD)
The results of hypothesis testing explain that organizational commitment has a positive and significant effect on performance. This study supports the findings of Karen et al (2019): Eliyana et al. (2019); Loans (2020), and Jung et al (2021), which states the same thing that there is a positive and significant influence between organizational commitment to performance. Changes in organizational commitment variables with affective, normative, and ongoing commitment towards more (positive) dimensions can improve performance. This is supported by researchAyu et al. (2018) and Maryani et al. (2021). The next concern in this study is the dimension of normative commitment, which also provides direction that the indicator of this dimension has a level of validity to measure the dimension of normative commitment. For example, firmness in carrying out applicable rules, evaluating and setting sanctions for the achievements of their respective duties and responsibilities, and enforcing civil servant discipline is supported by research Maryani et al., 2021). Furthermore, in this study, affective commitment gives a low mean value; employees are willing to remain in the organization, have faith in its goals, have high confidence in it, and maintain themselves want to stay part of the organization. Other findings by Chen et al. (2021) explain how cognitive and affective beliefs influence cooperative behavior.

Competence has a positive and significant impact on the Performance of Regional Apparatus Organizations (OPD)

This study explains that HR competence in improving its performance is very important to pay attention to, especially in the dimensions of Technical Competence, Managerial Competence, and Socio-Cultural Competence. Attention to HR competencies is directed at the dimension that has the highest mean value, the first highest being the socio-cultural dimension. This research is supportedAndiola et al. (2020), Deng et al. (2020), and Nguyen et al. (2020). On the other hand, it can be explained that the managerial dimension of HR competence, where managerial competence has the second-highest average value, is supported by (Rahayu et al., 2021; Ahmad \& Ahmad, 2021; Felicio et al., 2021). Next is the technical competence dimension that supports organizational performance achievement; this research is supported by (Krage et al., 2017; Dawson \& Thomson, 2018; Ahmed \& Mohamed, 2020; Hutagalung et al., 2020 and Nguyen et al., 2020).

Information Technology has a positive and significant effect on the Performance of Regional Apparatus Organizations (OPD)

The results show that information technology has a positive and significant effect on performance. This research is supported by research (Kong et al., 2020) that shows a positive relationship between IT implementation and employee performance. In addition, empirical results support that performance measurement associated with cost reduction and lead time shortening in internal processes and quality 
improvement in external processes can improve performance. This research is also in line with the study (Huang et al., 2015; Chatterjee et al., 2021; Al Samman \& Al Aathem, 2020). Furthermore, this dissertation research can be explained that information technology can improve performance. This is in line with previous research by Rachman \& Nuraeni (2020) and (Chege et al., 2020).

Furthermore, it is explained that government policies should aim to improve ICT infrastructure; establish an ICT resource center to support performance. The results imply that effective IT is an important aspect that must be considered to achieve successful e-government development in Indonesian local governments. This research is supported by research(Sofyani et al., 2020; Dea et al., 2020; Farnaghi \& Mansourian, 2020).

The Performance of Regional Apparatus Organizations (OPD) has a positive and significant impact on Job Satisfaction.

The results of this study that performance has a positive and significant effect on job satisfaction. Based on the recapitulation of the value of the performance variable on the dimension of growth perspective, it has the highest mean value. The importance of increasing budget control and transparency that can benefit society has been supported by research (Hu et al., 2020; Ahrens \& Ferry, 2020; Nemec \& tepaček, 2020 and Dollery et al., 2020). The second dimension of the highest mean value is the customer perspective dimension. The Performance of Program and Activity Achievements should be oriented to the community's needs, oriented to the results achieved (outputs) according to the target. The programs and activities provide benefits that the community feels or the outcomes or impacts of these activities. It has been supported by research by Marzuki et al. (2020): O'Hagan et al. (2020); Jayasinghe et al. (2020). The next dimension in the performance of the Balanced Score Card (BSC) approach is the internal business process dimension which is considered very important. The process of innovation in program and activity planning is based on the identification of community needs, carrying out an evaluation and monitoring process of budget wastage, the process of identifying sources of budget wastage, and the process of improving services to stakeholders; these results are supported by (Huđek et al., 2021; Roth Cardoso et al., 2020 and Dollery et al., 2020). Outcome performance, seen from the economic dimension, ranks last as the respondent's assessment, four indicators are assessed, namely the performance of program and activity achievements, paying attention to budget absorption per TW, paying attention to the outcome of the budget issued, paying attention to the benefits following the funding and having an impact in the long term. . The results of this study are supported by(Alimudin et al., 2019; Ima Apriani et al., 2020; Al-ahdal et al., 2020 and Tahar et al., 2021). This is different from the empirical studies of several previous researchers who place satisfaction as a variable that mediates performance, meaning that the higher the employee's job satisfaction, the higher the employee's performance. This result is supported (Alsafadi \& Altahat, 2021; Jamal Ali \& Anwar, 2021; Paais \& Pattiruhu, 2020).

Organizational commitment has a positive and significant effect on job satisfaction.

The results of this study indicate that organizational commitment has a positive but not significant effect on job satisfaction. The results of this study do not support the research conducted by Kaya et al. (2013), which explains that organizational commitment has a positive and significant effect on job satisfaction. Furthermore, Kaya et al. (2013) show that job attitudes positively but not significantly impact job satisfaction and employee performance. Similarly, the research results by Ruddin et al. (2020) stated that work commitment has a positive impact on satisfaction. Furthermore, this dissertation research can be explained that organizational commitment that is built positively can increase job satisfaction, although not significantly to job satisfaction. Organizational commitment increases towards the better (positive), then job satisfaction has no significant effect, or changes in job satisfaction are low/no.

Competence has a positive and significant effect on Job Satisfaction.

The results of this study indicate that HR competence has a positive and significant effect on job satisfaction. This research was supported byTahir et al, (2020), Alvianna \& Danang, (2021) and Dadang et al, (2020). The results showed that competence has a significant impact on employee job satisfaction. Attention to job satisfaction, especially on indicators that employees have feelings of pleasure in the work carried out following their main tasks, feelings of pleasure with salaries received as structural allowances as echelon positions; feeling happy about the additional budget ceiling if it achieves performance, and feeling happy about the lack or absence of findings from the supervision/inspection of the Inspectorate and BPK, as well as feeling happy about all programs and activities that can provide benefits and impacts to the community. Based on the above findings,

\section{Information Technology has a positive and significant effect on Job Satisfaction.}

The results of this study indicate that information technology has a positive and significant effect on job satisfaction. This research was supported byAmirudin et al. (2021), and Susilawati (2020) explained that the e-System has a substantial impact on job satisfaction. Likewise, the research results in Markham (2009); Lin et al. (2019); Hendriyaldi \& Musnaini (2021); (Harjanto et al., 2020); Sapta et al. (2021). This study succeeded in proving a positive and significant relationship between information technology support facilities on job satisfaction, information technology support facilities on information systems, organizational culture on information systems, and information systems on job satisfaction. Increasing the use of technology towards a better (positive) 
direction will significantly increase job satisfaction. Attention to the use of information technology to encourage transparency and accountability, reduce costs, improve services for the community, shorten working time more efficiently, simplify work control, and facilitate work integration. Based on the theory that the characteristics of quality information according to Mcleod (2010), there are four, namely accurate, timely, relevant, and complete.

\section{CONCLUSION}

Based on the results and discussion of the research, it can be concluded that organizational commitment has a positive and significant effect on the performance of the Regional Apparatus Organization (OPD) of the Tojo Una-Una Regency Government; Competence has a positive and significant impact on the performance of the Regional Apparatus Organization (OPD) of the Tojo Una-Una Regency Government; Information technology has a positive and significant impact on the performance of the Regional Apparatus Organization (OPD) of the Tojo Una-Una Regency Government; The performance of the Regional Apparatus Organization (OPD) of the Tojo Una-Una Regency Government has a positive but not significant effect on job satisfaction; Organizational commitment has a positive and significant impact on job satisfaction of the Regional Apparatus Organization (OPD) of the Tojo Una-Una Regency Government;

Based on the results of the study, it is recommended to increase sustainable commitments, significantly strengthening the awareness that they will continue to work well because they feel the economic benefits they receive; Improving Sociocultural, by increasing trustworthiness, disciplined work culture, social nature towards subordinates, and Teamwork culture; Encouraging the use of information technology, especially in e-planning and e-government applications, to increase efficiency and working time, promote transparency and accountability, improve public services, and work coordination; Improving performance through growth and learning perspectives, namely minimizing SiLPA, so that activities that are not yet on target can be used as learning for future improvements,

\section{REFERENCES}

[1] Abbas, Q., \& Yaqoob, S. (2009). Effect of leadership development on employee performance in Pakistan. Pakistan Economic and Social Review, 269-292

[2] Achmad Rozi, Bagaskoro, Joko Nugroho, Evalina, Jamalus, D. S. V. P. M. (2021). Effect of Transformational , Transactional Leadership and Job Satisfaction: Evidence from Information Technology Industries. Information Technology In Industry, 9(1), 987-996.

[3] Ahmad, I., \& Ahmad, S. Bin. (2021). Effect Of Managerial Skills On The Performance Of Small-And Medium-Sized Enterprises: A Case Study In Pakistan. Journal Of Asian Finance, Economics And Business, 8(4),161-170.

[4] Ahmed, S., \& Mohamed, S. A. (2020). Article Id: Ijm_11_11_158 Cite This Article: Sajid Ahmed Mohamed And Kinslin, Exploration On Competent Technical Skills Of Manager In Decision Making Of A Business Management: A Survey Analysis. International Journal Of Management (Ijm), 11(11), 1658-1667.
[5] Ahrens, T., \& Ferry, L. (2020). Financial Resilience Of English Local Government In The Aftermath Of Covid-19. Journal Of Public Budgeting, Accounting And Financial Management, 32(5), 813-823.

[6] Akram, M., \& Anwer, M. (943). Relationship of Teacher Competence with Professional Commitment and Job Satisfaction at Secondary Level Locus of Control and Intention towards Adaptability of Entrepreneurship: Students' Perspective. View project A student thesis View project.

[7] Al Samman, A., \& Al Aathem, M. (2020). How Information Technology Affects Hr Performance Development In Service Sectors Discovering The Impact Of Training Effectiveness Commitment On Organizational Change View Project.

[8] Al Zefeiti, Salim,Musabah Bakhit, Noor Azmi Mohamad. (2017). The Influence of Organizational Commitment on Omani Public Employees' Work Performance. International Review of Management and Marketing.Vol 7 Issue 2.

[9] Al-Ahdal, W. M., Alsamhi, M. H., Tabash, M. I., \& Farhan, N. H. S. (2020). The Impact Of Corporate Governance On Financial Performance Of Indian And Gcc Listed Firms: An Empirical Investigation. Research In International Business And Finance, 51, 101083.

[10] Ali Ghazi Imad Azez Nashmie Asaad Tariq, H. (2021). Modern information technology and its role in improving the performance of sports management Directorates and forums for youth and sports in Iraq. Modren Sport Journal.

[11] Alimudin, A., Falani, A. Z., Mudjanarko, S. W., \& Limantara, A. D. (2019). Analisis Pengaruh Penerapan Perspektif Balanced Scorecard Terhadap Peningkatan Kinerja Umkm. Ekonika : Jurnal Ekonomi Universitas Kadiri, 4(1),1.

[12] Alsafadi, Y., \& Altahat, S. (2021). Human Resource Management Practices And Employee Performance: The Role Of Job Satisfaction. Journal Of Asian Finance, Economics And Business, 8(1), 519-529.

[13] Alvianna, S., \& Danang Setioko, M. (2021). Analysis Of The Influence Of Tourist Destinations And Service Quality On Tourist Satisfaction Visiting The Jawa Timur Park In The New Normal Era Strategic Management View Project Tourism View Project Analysis Of The Influence Of Tourist Destinations And Service Quality On Tourist Satisfaction Visiting The Jawa Timur Park In The New Normal Era. In International Journal Of Innovative Science And Research Technology (Vol. 6, Issue 1).

[14] Amirudin, A., Sihite, M., \& Supriadi, E. (2021). Pengaruh ESystem Sdm, Lingkungan Kerja Terhadap Kinerja Karyawan Melalui Kepuasan Kerja Dan Motivasi Kerja. In Jurnal Akuntansi Aktiva (Vol. 2, Issue 1).

[15] Andika Thio Rahman, R., Irianto, G., \& Rosidi, R. (2019). Evaluation of E-Budgeting Implementation in Provincial Government of DKI Jakarta Using CIPP Model Approach. Journal of Accounting and Investment, 20(1).

[16] Andiola, L. M., Downey, D. H., \& Westermann, K. D. (2020). Examining Climate And Culture In Audit Firms: Insights, Practice Implications, And Future Research Directions. Auditing, 39(4), 129.

[17] Araújo, M., Lopes, P. (2014), Virtuous leadership, organizational commitment and individual performance. Review of Applied Management Studies, 12, 3-10.

[18] Argensia, Ritha F.Dalimunthe, Sitti Raha Agoes Salim. 2014. Analisis Pengaruh Kepuasan Kerja dan Motivasi Terhadap Kinerja Pegawai dengan Komitmen Organisasional sebagai Variabel Intervening (Studi Pada Kantor Pengawasan dan Pelayanan Bea dan Cukai Tipe Madya Pabean B Medan). Jurnal Ekonomi. Vol.17 No.2 April 2014

[19] Aytac Gokmen (2010). Developments And Prospects In EGovernment Implementations In Turkey. International Journal Of Ebusiness And Egovernment Studies Vol 2, No 2, 2010 Issn: 2146-0744 (Online).

[20] Ayu, I., Martini, O., Ketut Rahyuda, I., Sintaasih, D. K., \& Piartrini, P. S. (2018). The Influence Of Competency On Employee Performance Through Organizational Commitment 
Dimension Want More Papers Like This? The Influence Of Competency On Employee Performance Through Organizational Commitment Dimension. 20, 29-37.

[21] Aziri, B. (2011). Job satisfaction: A literature review. Management research and practice, 3(4), 77-86.

[22] Bobe, B. J., Mihret, D. G., \& Obo, D. D. (2017). Public-sector reforms and balanced scorecard adoption: an Ethiopian case study. Accounting, Auditing and Accountability Journal, 30(6), 12301256.

[23] Bos, J. T., Donders, N. C., Bouwman-Brouwer, K. M., \& Van der Gulden, J. W. (2009). Work characteristics and determinants of job satisfaction in four age groups: university employees' point of view. International archives of occupational and environmental health, 82(10), 1249-1259.

[24] Casimir, G., Ngee Keith Ng, Y., Yuan Wang, K., Ooi, G. (2014), The relationships amongst leader-member exchange, perceived organizational support, affective commitment, and in-role performance: A social-exchange perspective. Leadership and Organization Development Journal, 35(5), 366-385.

[25] Chanda, U., \& Goyal, P. (2020). A Bayesian network model on the interlinkage between Socially Responsible HRM, employee satisfaction, employee commitment and organizational performance. Journal of Management Analytics, 7(1), 105-138.

[26] Chatterjee, S., D Moody, G., Lowry, P. B., Chakraborty, S., \& Hardin, A. (2021). The Nonlinear Influence Of Harmonious Information Technology Affordance On Organisational Innovation. Information Systems Journal, 31(2), 294-322.

[27] Che, C., Koo, B., Wang, J., Ariza-Montes, A., Vega-Muñoz, A., \& Han, H. (2021). Promoting rural tourism in inner mongolia: Attributes, satisfaction, and behaviors among sustainable tourists. International Journal of Environmental Research and Public Health, 18(7), 3788 .

[28] Chege, S. M., Wang, D., \& Suntu, S. L. (2020). Impact Of Information Technology Innovation On Firm Performance In Kenya. Information Technology For Development, 26(2), 316345.

[29] Chen, S. (Joseph), Waseem, D., Xia, Z. (Raymond), Tran, K. T., Li, Y., \& Yao, J. (2021). To Disclose Or To Falsify: The Effects Of Cognitive Trust And Affective Trust On Customer Cooperation In Contact Tracing. International Journal Of Hospitality Management, 94, 102867.

[30] Dadang Pramana Aprilliansyah, P., Chalid, I., \& Muhammadiyah Kalimantan Timur, U. (2020). Pengaruh Kompetensi Terhadap Kepuasan Kerja Pegawai Dinas Perkebunan Provinsi Kalimantan Timur. In Borneo Student Research (Bsr) (Vol. 2, Issue 1).

[31] Dadang Suwanda, (2015). Factor Effecting Quality of Local Government Financial Statement to Get Unqualified Opinion (WTP) of Audit Board of The Republic of Indonesia (BPK). Research Journal of Finance and Accounting. Vol 6 No. 4, 139157.

[32] Dash, Satyabrata \& Subhendu Kumar Pani. (2016). e-Governance paradigm using cloud infrastructure: benefits and challenges. Procedia Computer Science 85 (2016) 843-855.

[33] Dawson, J., \& Thomson, R. (2018). The Future Cybersecurity Workforce: Going Beyond Technical Skills For Successful Cyber Performance. In Frontiers In Psychology (Vol. 9, Issue Jun, P. 744). Frontiers Media S.A.

[34] Dea, M., Mapa, L., Laka, W., \& Bambang Suprasto, H. (2020). Accountability, Information Technology And Village Performance. International Research Journal Of Management, $7(2), 71-78$

[35] Deng, H., Walter, F., \& Guan, Y. (2020). Supervisor-Directed Emotional Labor As Upward Influence: An Emotions-As-SocialInformation Perspective. Journal Of Organizational Behavior, 41(4), 384-402.

[36] Destari, Y., Lumbanraja, P., \& Absah, Y. (2018). The Influence of Work Satisfaction on Employees Performance with Organizational Commitment as Intervening Variable at Mining and Energy Agency of North Sumatera. International Journal of Scientific and Technology Research, 5(12), 355-364.
[37] Dollery, B., Kitchen, H., Mcmillan, M., \& Shah, A. (2020). Measuring And Monitoring Local Government Performance. In Local Public, Fiscal And Financial Governance (Pp. 201-227). Springer International Publishing.

[38] Eliyana, A., Ma'arif, S., \& Muzakki. (2019). Job Satisfaction And Organizational Commitment Effect In The Transformational Leadership Towards Employee Performance. European Research On Management And Business Economics, 25(3), 144-150.

[39] Farnaghi, M., \& Mansourian, A. (2020). Blockchain, An Enabling Technology For Transparent And Accountable Decentralized Public Participatory Gis. Cities, 105, 102850.

[40] Felício, T., Samagaio, A., \& Rodrigues, R. (2021). Adoption Of Management Control Systems And Performance In Public Sector Organizations. Journal Of Business Research, 124, 593-602.

[41] Ferdinand, Augusty. 2014. Metode Penelitian Manajemen. Edisi 5. Semarang : 60 Badan Penerbit Universitas Diponegoro.

[42] Fifien Dhesta Listiyana, (2015). Influence of Leadership Style, Discipline, Organizational Culture, Motivation and Organizational Commitment to Performance of Regional Finance Manager (Study on Revenue Service, Financial Management and Regional Asset of Wonogiri Regency). Faculty of Economics, University of Muhammadiyah Surakarta.

[43] Folorunso, O.O., Adewale, A.J., Abodunde, S.M. (2014), Exploring the effect of organizational commitment dimensions on employees performance: An empirical evidence from Academic Staff of Oyo State Owned Tertiary Institutions, Nigeria. International Journal of Academic Research in Business and Social Sciences, 4(8), 275-286.

[44] Fu, W., Deshpande, S.P. (2014), The impact of caring climate, job satisfaction, and organizational commitment on job performance of employees in a China's insurance company. Journal of Business Ethics, 124(2), 339-349.

[45] Gede, I., Kawiana, P., Komang, L., Dewi, C., Kadek, L., Martini, B., Bagus, I., \& Suardana, R. (2018). The Influence of Organizational Culture, Employee Satisfaction, Personality, and Organizational Commitment towards Employee Performance. International Research Journal of Management.

[46] Gopinath, R. (n.d.). Organisational Commitment And Job Satisfaction Relationship-A Study In Private Cement Factories.

[47] Gunawan, H., Haming, M., Zakaria, J., \& Djamareng, A. (2017). Effect of Organizational Commitment, Competence and Good Governance on Employees Performance and Quality Asset Management. IRA-International Journal of Management \& Social Sciences (ISSN 2455-2267), 8(1), 17.

[48] Hair, J.F., Black, W.J., Babin, B.J., \& Anderson, R.E. (2014). Multivariate data analysis. Englewood Cliff, NJ: Prentice Hall.

[49] Harjanto, H., Widjajanti, K., \& Sugiarti, L. R. (2020). Sarana Teknologi Dan Budaya Organisasi Terhadap Kepuasan Kerja Dimediasi Sistem Informasi. Jurnal Riset Ekonomi Dan Bisnis, 13(3), 212.

[50] Harun, H. 2012. Institutionalization of accrual accounting in the Indonesian public sector. Journal of Accounting and Organizational Change, 8(3), 257-285

[51] Hasibuan, ZA dan Santoso, HB. (2005). Standardisasi aplikasi egovernment untuk instansi pemerintah. Prosiding Konferensi Nasional Teknologi Informasi dan Komunikasi Indonesia. ITB.

[52] Hendriyaldi, \& Musnaini. (2021). Analisis Pengaruh Pelayanan Publik Dan E-Service Quality Terhadap Kepuasan Masyarakat Di Lingkungan Pemerintahan Kota Jambi. Jurnal Manajemen Terapan Dan Keuangan, 10(01), 87-98

[53] Hu, Q., Zhang, L., Zhang, W., \& Zhang, S. (2020). Empirical Study On The Evaluation Model Of Public Satisfaction With Local Government Budget Transparency: A Case From China. Sage Open, 10(2).

[54] Huang, S. Y., Lee, C. H., Chiu, A. A., \& Yen, D. C. (2015). How Business Process Reengineering Affects Information Technology Investment And Employee Performance Under Different Performance Measurement. Information Systems Frontiers, 17(5), 1133-1144.

[55] Huđek, I., Tominc, P., \& Širec, K. (2021). The Impact Of Social 
And Cultural Norms, Government Programs And Digitalization As Entrepreneurial Environment Factors On Job And Career Satisfaction Of Freelancers. Sustainability (Switzerland), 13(2), 121.

[56] Hulin, C. L. (2001). Lessons from I/O psychology. In F. D. Drasgow \& J. M. Brett (Eds), Psychology of work: Theoretically based empirical research. Mahwah, NJ: Lawrence Erlbaum.

[57] Hutagalung, D., Sopa, A., Asbari, M., Cahyono, Y., Maesaroh, S., Chidir, G., \& Sutardi, D. (N.D.). Journal Of Critical Reviews Influence Soft Skills, Hard Skills And Organization Learning On Teachers` Teachers`Performance Through Inovation Capabilityas Mediator.

[58] Huy, P. Q., \& Phuc, V. K. (2020). The impact of public sector scorecard adoption on the effectiveness of accounting information systems towards the sustainable performance in public sector. Cogent Business and Management.

[59] Ima Apriani, E., Pangiuk, A., \& Hafiz, A. P. (2020). Pengaruh Metode Balanced Scorecard Terhadap Kinerja Pada Bank Syariah Mandiri Kcp Jelutung Kota Jambi.

[60] Irvan, N., Mus, A. R., Su'un, M., \& Sufri, M. (2017). Effect of Human Resource Competencies, Information Technology and Internal Control Systems on Good Governance and Local Government Financial Management Performance. IRAInternational Journal of Management \& Social Sciences (ISSN 2455-2267), 8(1), 31.

[61] Jamal Ali, B., \& Anwar, G. (2021). An Empirical Study Of Employees' Motivation And Its Influence Job Satisfaction. International Journal Of Engineering, Business And Management, $5(2), 21-30$.

[62] Jayasinghe, K., Adhikari, P., Carmel, S., \& Sopanah, A. (2020). Multiple Rationalities Of Participatory Budgeting In Indigenous Communities: Evidence From Indonesia. Accounting, Auditing And Accountability Journal, 33(8), 2139-2166.

[63] Judge, T. A., Weiss, H. M., Kammeyer-Mueller, J. D., \& Hulin, C. L. (2017). Job attitudes, job satisfaction, and job affect: A century of continuity and of change.

[64] Jung, H. S., Song, M. K., \& Yoon, H. H. (2021). The Effects Of Workplace Loneliness On Work Engagement And Organizational Commitment: Moderating Roles Of Leader-Member Exchange And Coworker Exchange. Sustainability (Switzerland), 13(2), 115.

[65] Kabiru J. Ringim, Mocd R. Razalli \& Norlenna Hasnan.(2015). The Relationship between Information Technology Capability and Organizational Performance in Nigerian Banks. International Journal Of Bussiness Research and DevelopmentVol 4 No. 2. pp $1-10$.

[66] Kalkavan, S., Katrinli, A. (2014), The effects of managerial coaching behaviors on the employees perception of job satisfaction, organisational commitment, and job performance: Case study on insurance industry in Turkey. Procedia-Social and Behavioral Sciences, 150, 1137-1147.

[67] Kaplan, R. S., \& Norton, D. P. (1996). The balanced scorecard: Translating strategy into action. Harvard Business School Press, Boston, MANor.

[68] Karem, M. A., Mahmood, Y. N., Jameel, A. S., \& Rahman Ahmad, A. (2019). The Effect Of Job Satisfaction And Organizational Commitment On Nurses' Performance. Humanities \& Social Sciences Reviews, 7(6), 332-339.

[69] Karem, M. A., Mahmood, Y. N., Jameel, A. S., \& Rahman Ahmad, A. (2019). The Effect Of Job Satisfaction And Organizational Commitment On Nurses' Performance. Humanities \& Social Sciences Reviews, 7(6), 332-339.

[70] Kaya, Y., Susanty, A., Miradipta, R., \& Jie, F. (2013). Ejbss-121190-Analysisoheeffectofattitudetowardworks Want More Papers Like This? Analysis Of The Effect Of Attitude Toward Works, Organizational Commitment, And Job Satisfaction, On Employee's Job Performance (Case Study In Electronic Company). In European Journal Of Business And Social Sciences (Vol. 1, Issue 10).

[71] Kendall, L. M. (1963). Canonical analysis of job satisfaction and behavioral, personal background, and situational data. Unpublished doctoral dissertation, Cornell University.

[72] Kong, W. H., Loi, K. I., \& Xu, J. (2020). Investigating Destination Loyalty Through Tourist Attraction Personality And Loyalty. Journal Of China Tourism Research.

[73] Krage, R., Zwaan, L., Tjon Soei Len, L., Kolenbrander, M. W., Van Groeningen, Di., Loer, S. A., Wagner, C., \& Schober, P. (2017). Relationship Between Non-Technical Skills And Technical Performance During Cardiopulmonary Resuscitation: Does Stress Have An Influence?. Emergency Medicine Journal, 34(11), 728-733.

[74] Krajcsák, Z. (2021). Modelling organizational conflict processes: the organizational value of employee commitment and the moderating role of transformational leadership. Journal of Modelling in Management, ahead-of-

[75] Kreitner Robert \& Angelo Kinicki (2014). Perilaku Organisasi. Jakarta: Salemba Empat

[76] Lestari \& Zulaikha, (2007). Influence of Information Technology Relatedness to Company Performance with Knowledge Management Capability as Intervening variable (Empirical Study on Banking Company in Central Java). National Symposium on Accounting X Makassar.Mahmudi, Manajemen Kinerja Sektor Publik. UPP AMP YKPN, Yogyakarta.

[77] Lin, C. Y., Huang, C. K., \& Zhang, H. (2019). Enhancing Employee Job Satisfaction Via E-Learning: The Mediating Role Of An Organizational Learning Culture. International Journal Of Human-Computer Interaction, 35(7), 584-595.

[78] Loan, L. T. M. (2020). The Influence Of Organizational Commitment On Employees' Job Performance: The Mediating Role Of Job Satisfaction. Management Science Letters, 10(14), $3307-3312$.

[79] Lotunani, A., Idrus, M. S., Afnan, E., \& Setiawan, M. (2014). The Effect of Competence on Commitment, Performance and Satisfaction with Reward as a Moderating Variable ( A Study on Designing Work plans in Kendari City Government, Southeast Sulawesi ). International Journal of Business and Management Invention, 3(2), 18-25.

[80] Luoto, M., Rekolainen, S., Salt, C. A., \& Hansen, H. S. (2001). Managing radioactively contaminated land: Implications for habitat diversity. Environmental Management, 27(4), 595-608.

[81] Macey, W.H., Schneider, B. (2008), The meaning of employee engagement. Industrial and Organizational Psychology, 1(1), 3-30.

[82] Markham, L. M. (2009). Perceptions Of Motivation And Job Satisfaction For Information Technology Professionals At Institutions Of Higher Learning In Mississippi. Mississippi State University.

[83] Maryani, Y., Entang, M., \& Tukiran, M. (2021). International Journal Of Social And Management Studies (Ijosmas) The Relationship Between Work Motivation, Work Discipline And Employee Performance At The Regional Secretariat Of Bogor City. In International Journal Of Social And Management Studies (Vol. 2, Issue 2).

[84] Marzuki, S., Laksmono, B. S., \& Subroto, A. (2020). Improving Government's Performance Management By Using The Balanced Scorecard On Stakeholders Perspectives. Journal Of The Community Development In Asia, 3(3), 29-47.

[85] Maulana Ihsan (2018). Tata Kelola Pemerintahan di Era Revolusi Industri 4.0. Diakses Tanggal 24 Oktober. https://kumparan.com/maulana-ihsan1522156960298/tata-kelolapemerintahan-di-era-revolusi-industri-4-0.

[86] Mcleod, Raymod. 2010. Sistem Informasi Manajemen. Jakarta : Salemba Empat

[87] Mowday, R. T., R. M. Steers and I. W. Porter (1983). The Measurement of Organizational Commitment. Journal of Applied Psychology. Vol.84, p.408414.

[88] Muda, I., Wardani, D. Y., Erlina, Maksum, A., Lubis, A. F., Bukit, R., \& Abubakar, E. (2017). The influence of human resources competency and the use of information technology on the quality of local government financial report with regional accounting system as an intervening. Journal of Theoretical and Applied 
Information Technology, 95(20), 5552-5561.

[89] Mustofa Usman, Faiz A.M. Elfaki and Jamal I. Daoud. (2013). Ratio of Linear Function of Parameters and Testing Hypothesis of the Combination Two Split Plot Designs. Middle-East Journal of Scientific Research 13 (Mathematical Applications in Engineering): 109-115, 2013 ISSN 1990-9233 (C) IDOSI Publications, 2013 DOI: 10.5829/idosi.mejsr.2013.13.mae.10002.

[90] Natalia Dewinda Putri, (2010). The Effect of Organizational Commitment and Role of Regional Financial Management Manager to Managerial Performance of Regional Device Work Unit. Faculty of Economics, Diponegoro University, Semarang.

[91] Nemec, J., \& Špaček, D. (2020). The Covid-19 Pandemic And Local Government Finance: Czechia And Slovakia. Journal Of Public Budgeting, Accounting And Financial Management, 32(5), 837-846.

[92] Nguyen, P. T., Yandi, A., \& Mahaputra, M. R. (2020). Factors That Influence Employee Performance: Motivation, Leadership, Environment, Culture Organization, Work Achievement, Competence And Compensation (A Study Of Human Resource Management Literature Studies). Dinasti International Journal Of Digital Business Management, 1(4), 645-662.

[93] Nhuta, S., \& Nhuta, P. (2017). Job Satisfaction Levels and Motivation among Teachers; A Comparative Analysis of Teachers in Government Public and Private Schools. Journal of Educational Policy and Entrepreneurial Research, 4(1), 36-60.

[94] Niemiec, C. P., \& Spence, G. B. (2017). Optimal Motivation at Work. The Wiley Blackwell Handbook of the Psychology of Positivity and Strengths Based Approaches at Work, 82-98.

[95] Noe, Raymond A ( 2002). Employee Training and Development. Second Edition. New York: McGraw-Hill Irwin.

[96] Nor, Wahyudin. 2012. Penerapan Balanced Scorecard Pada Pemerintah Daerah. AUDI Jurnal Akuntansi \& Bisnis, Vol. 7, No. 2, Juli 2012

[97] Nurul Hidayah dan Wahyudin Zarkasyi (2017). The Effect of Human Resources Management Competency and the Role of Culture on Accrual Accounting Implementation Effectiveness and the Impact on Quality of Accounting Information. European Research Studies Journal Volume XX, Issue 4B, 2017. pp. 183199.

[98] O'hagan, A., Macrae, C., O'connor, C. H., \& Teedon, P. (2020). Participatory Budgeting, Community Engagement And Impact On Public Services In Scotland. Public Money And Management, 40(6), 446-456.

[99] Oktaviane, D. P. (2021). Evaluasi Kinerja Badan Pengelola Keuangan Dan Aset Daerah Kota Padang Menurut Perspektif Balanced Scorecard. Jess (Journal Of Education on Social Science), 5(1), 109

[100] Paais, M., \& Pattiruhu, J. R. (2020). Effect Of Motivation, Leadership, And Organizational Culture On Satisfaction And Employee Performance. Journal Of Asian Finance, Economics And Business, 7(8), 577-588.

[101] Rachman, G. G., \& Nuraeni, S. (2020). The Influence Of Information Technology And Management Control Systems On Employee Performance. Jasa (Jurnal Akuntansi, Audit Dan Sistem Informasi Akuntansi), 4(3), 365-377.

[102] Rahayu, R., Gusma Putra, D., \& Putri, A. (2021). The Influence Of Enterprise Resource Planning (Erp) Implementation System On Company Performance Mediated By Organizational Capabilities. Article In Journal Of Accounting And Investment, 22(2).

[103] Rahman, Abdul \& Fachri, Zulkifli. (2016). Region's Financial Accounting Information System and The Quality of Local Government Financial Reports. International Journal Of Information Management and Bussiness Review Vol 8 No. 4.. pp 64-68.

[104] Rantelangi, C., Affan, N., Deviyanti, D. R., \& I R Sari, W. (2018). The Influence of Organizational Commitment, Auditor Independence, Internal Control, and Ethical Leadership in Good Governance and Organizational PerformanceGood Governance and Organizational Performance. 35(Miceb 2017), 236-242.

[105] Ridlwan, M., Purwandari, D. A., \& Rahmat Syah, T. Y. (2021).
The Effect of Situational Leadership and Organizational Culture on Employee Performance Through Job Satisfaction. International Journal of Multicultural and Multireligious Understanding, 8(3), 73.

[106] Robbins, Stephen dan Thimoty P Judge (2018). Perilaku Organisasi. Edisi keenam belas. Salemba Empat. Jakarta.

[107] Robbins, Stephen P dan Mary Coulter. (2010). Manajemen. Jakarta: Edisi Kesepuluh. Jakarta: Erlangga.

[108] Rosita, Titik dan Tri Yuniati. 2016. Pengaruh Kepuasan Kerja Terhadap Kinerja Karyawan dengan Komitmen Organisasional sebagai Variabel Intervening. Jurnal Ilmu dan Riset Manajemen. Vol.5 No.1 Januari 2016.

[109] Roth Cardoso, H. H., Dantas Gonçalves, A., Dambiski Gomes De Carvalho, G., \& Gomes De Carvalho, H. (2020). Evaluating Innovation Development Among Brazilian Micro And Small Businesses In View Of Management Level: Insights From The Local Innovation Agents Program. Evaluation And Program Planning, 80, 101797.

[110] Ruddin, S., Mus, A. R., Latief, B., \& Andriani, B. (2020). Organizational Culture, Work Commitment And Compensation Effect On Job Satisfaction And Police Members Performance In Makassar Metropolitan City Police (Polrestabes). European Journal Of Business And Management Research, 5(2).

[111] Rue, L., \& Byars, L. (2003). Management: Skills \& Application. McGraw-Hill Higher Education.

[112] Sabuhari, R., Sudiro, A., Irawanto, D. W., \& Rahayu, M. (2020). The effects of human resource flexibility, employee competency, organizational culture adaptation and job satisfaction on employee performance. Management Science Letters, 10(8), 1777-1786.

[113] Sani, A. (2013). Role of procedural justice, organizational commitment and job satisfaction on job performance: The mediating effects of organizational citizenship behavior. International Journal of Business and Management, 8(15), 57.

[114] Sapta, I. K. S., Muafi, M., \& Setini, N. M. (2021). The Role Of Technology, Organizational Culture, And Job Satisfaction In Improving Employee Performance During The Covid-19 Pandemic. Journal Of Asian Finance, Economics And Business, 8(1), 495-505.

[115] Saputra, M. R. E. (2020). Pengaruh Komitmen Organisasional Dan Kepuasan Kerja Terhadap Motivasi Guru Di Smp Negeri 18 Kota Pontianak.

[116] Sekaran, Uma dan Bougie, Roger. (2017). Metode Penelitian untuk Bisnis: Pendekatan keahlian. West Sussex: Wiley. Penerbit Salemba Empat.

[117] Sharma, S., Prakash, G., Kumar, A., Mussada, E. K., Antony, J., \& Luthra, S. (2021). Analysing the relationship of adaption of green culture, innovation, green performance for achieving sustainability: Mediating role of employee commitment. Journal of Cleaner Production, 303, 127039.

[118] Sofyani, H., Riyadh, H. A., \& Fahlevi, H. (2020). Improving Service Quality, Accountability And Transparency Of Local Government: The Intervening Role Of Information Technology Governance. Cogent Business And Management, 7(1), 1735690.

[119] Spencer Jr, Lyle M., dan Signe M. Spencer (1993). Competence at Work: Models for Superior Performance. Edition. New Jersey: John Wiley \& Sons, Inc.

[120] Squires, J. E., Hoben, M., Linklater, S., Carleton, H. L., Graham, N., \& Estabrooks, C. A. (2015). Job Satisfaction among Care Aides in Residential Long-Term Care: A Systematic Review of Contributing Factors, both Individual and Organizational. Nursing Research and Practice.

[121] Sri Trisnaningsih. (2017). Auditor Independence And Organizational Commitment As Mediation Influence Of Understanding Good Governance, Leadership Style And Organizational Culture To Auditor Performance. Data and Business Center FEB UI. Jakarta.

[122] Sugiyono. (2015). Metode Penelitian Kuantitatif, Kualitatif, R dan D. Bandung: Penerbit Alfabeta.

[123] Susilawati, M. (2020). Pengaruh Teknologi Informasi Terhadapkepuasan Pengguna Dalam Penyusunanlaporan 
Keuangan Daerah:Perspektif Model Delone \& Mclone (Studi Pada Bpkad Kabupaten Luwu).

[124] Tahar, A., Aditya Prayoga Akuntansi, M., \& Muhammadiyah Yogyakarta, U. (2021). Pengaruh Tata Kelola Publik, Intergovernmental Revenue, Dan Kompetensi Terhadap Kinerja Pemerintah Daerah (Studi Empiris Pada Organisasi Perangkat Daerah Di Kabupaten Lombok Timur). In Jurnal Akuntansi Akunesa (Vol. 9, Issue 2).

[125] Tahir, A., Razak, M., Program, S. D., Manajemen, P. M., Nobel, S., \& Makassar, I. (2020). Nmar Nobel Management Review Pengaruh Kompetensi Sdm Dan Gaya Kepemimpinan Terhadap Kinerja Asn Melalui Kepuasan Kerja Pada Sekretariat Daerah Kabupaten Pinrang. In Nobel Management Review (Vol. 1, Issue 1).

[126] Wahab, W., Tinggi Ilmu Ekonomi Mahaputra Jl Paus No, S., Barat, T., \& Damai, M. (2021). Pengaruh Budaya Organisasi Dan Komitmen Organisasi Terhadap Kepuasan Kerja Karyawan Pada Pt. Sucofindo Cabang Pekanbaru. In Mapan: Jurnal Manajemen, Akutansi, Ekonomi, Perbankan (Vol. 1, Issue 2).

[127] Wahyu Maulid Adha, D. D. (2021). The Effect of Intellectual
Intelligence and Emotional Intelligence on Competence and Employees Performances. Jurnal Manajemen, 25(2), 222.

[128] Wang, J., Chen, C., Liu, Y., \& Barkley, D. (2020). Intercultural Competences And Job Satisfaction Of Expatriates: The Mediating Effect Of Positive Psychological Well-Being The International Journal Of Organizational Innovation. In Ijoi The International Journal Of Organizational Innovation (Vol. 12).

[129] Wang, W., Wang, Y., Zhang, Y., \& Ma, J. (2020). Spillover of workplace IT satisfaction onto job satisfaction: The roles of job fit and professional fit. International Journal of Information Management, 50, 341-352.

[130] Wigrantoro, (2003). Utilization of Information Technology in the Implementation of Good Governance. Seminar Paper "Good Governance Paradigm in a Competitive, Democratic and Transparent Information Era" was organized by Gunadarma University, Jakarta, on June 11.

[131] Yu, Y., Huo, B., \& Zhang, Z. (2021). Impact of information technology on supply chain integration and company performance: evidence from cross-border e-commerce companies in China. Journal of Enterprise Information Management, 34(1), 460-489. 